\title{
Dampak Perkawinan Yang Tidak Dicatat
}

\author{
Sarjiyati $^{1}$, Yuni Purwati ${ }^{2}$ \\ Fakultas Hukum, Universitas Merdeka Madiun, Jl. Serayu No.79, Madiun, 63133 \\ E-mail: sarjiyati.sh.mh@gmail.com \\ Fakultas Hukum, Universitas Merdeka Madiun, Jl. Serayu No.79, Madiun, 63133 \\ E-mail: yunipurwati@unmer-madiun.ac.id
}

\begin{abstract}
Marriage is a very important event in community life. Because marriage does not only concern the bride and groom, but also the parents of both parties, relatives and their families. The purpose of marriage is to form a happy and eternal family. The method used in this research juridical normative wiht analysis descriptive qualitative. The legal status of marriage that is not to noted under the marriage law is illegal or has no legal force. The legal status of a child born from a marriage that is not to noted has a civil relationship with his mother, this has the consequence that the child born of marriage is not to noted the country of the child does not have a civil relationship with his father. But after the decision of the Constitutional Court Number 46 / PUU-VIII / 2010 in which the child can also have a civil relationship with his father as long as it can be proven by technological tools such as DNA testing.
\end{abstract}

Keywords - : Marriage; not to noted; legal status; child's status.

\section{PENDAHULUAN}

Tuhan menciptakan segala makhluk di dunia secara berpasang-pasangan, termasuk makhluk ciptaan tuhan yang bernama manusia, adalah berpasang-pasangan yaitu laki-laki dan perempuan. Dalam kehidupan manusia antara laki-laki dan perempuan secara alamiah mempunyai daya tarik antara satu dengan yang lain dan apabila diantara mereka ada kecocokan kemudian akan sepakat untuk membentuk suatu rumah tangga yang bahagia dan kekal, hal ini merupakan suatu kodrat yang tidak dapat dihindari. Namun demikian manusia tidaklah dapat bebas berbuat semuanya sendiri akan tetapi harus taat, tunduk dan menghormati norma-norma yang berlaku termasuk peraturan perundang-undangan yang telah ditetapkan oleh negara.

Manusia adalah makhluk yang yang lebih dimuliakan dan diutamakan oleh Tuhan dibandingkan dengan makhlu-makhluk lainnya. Tuhan menetapkan adanya aturan tentang perkawinan bagi manusia ${ }^{1}$. Perkawinan merupakan sarana untuk membangun keluarga dalam suatu struktur yang bersifat khusus, satu sama lain dalam dalam keluarga itu mempunyai ikatan hubungan lewat darah atau lewat hubungan perkawinan. Ikatan tersebut membawa pengaruh dan saling berharap sesuai ajaran agama, dikukukhkan dengan kekuatan hukum dan secara individuai mempunyai ikatan batin sehingga memunculkan hak dan kewajiban dalam sebuah keluarga yang dibentuk dalam suatu perkawinan. ${ }^{2}$

Pengertian perkawinan sebagaimana termuat dalam ketentuan pasal 1 Undang-Undang Nomor 1 Tahun 1974 dinyatakan bahwa :"Perkawinan adalah ikatan lahir batin antara seorang pria dan seorang perempuan sebagai suami istri dengan tujuan untuk membentuk keluarga (rumah tangga) yang bahagia dan kekal berdasarkan Ke-Tuhanan Yang Maha Esa." ${ }^{3}$ Menurut Anwar Haryono perkawinana adalah suatu perjanjian yang suci antara seorang laki-laki dengan seorang wanita untuk membentuk keluarga bahagia. Jadi perkawinan merupakan suatu aqad untuk hidup sebagai suami istri yang sah , membentuk keluarga bahagia dan kekal. ${ }^{4}$.

Perkawinan merupakan peristiwa penting dalam kehidupan bermasyarakat. Sebab perkawinan tidak hanya menyangkut wanita dan pria mempelai saja, tetapi juga orang tua kedua belah pihak, saudara bahkan keluarga mereka masing-masing. Dalam Pasal 1angka 17 Undang-Undang Nomor 23 tahun 2006 Tentang Administrasi Kependudukan merumuskan peristiwa penting adalah kejadian yang dialami seseorang seperti kelahiran, kematian, lahir mati, perkawinan, perceraian, pengakuan anak, pengesahan anak, pengangkatan, perubahan nama, dan perubahan status kewarganegaraan ${ }^{5}$ Tujuan perkawinan untuk membentuk keluarga yang bahagia dan kekal untuk itu suami istri perlu saling membantu dan melengkapi agar masingmasing dapat mengembangkan kepribadiannya serta dapat membantu dan mencapai kesejahteraan spiritual dan materiil. ${ }^{6}$

Sahnya perkawinan diatur dalam pasal 2 ayat (1) dan ayat (2) Undang-Undang Nomor 1 tahun 1974. Pasal 2 ayat (1) yang berbunyi: "Perkawinan adalah sah, apabila dilakukan menurut hukum masing-masing agama dan kepercayaannya itu". Pasal 2 ayat (2) yang berbunyi: "Tiap-tiap perkawinan dicatat menurut peraturan perundang-undangan yang berlaku”. Berdasarkan bunyi

\footnotetext{
${ }^{1}$ H.A.S Al Hamdani, Risalah Nikah, Putakan Amani, Jakarta, 2002, hal. 1-2

${ }^{2}$ Siah Khosyi'ah, Akibat Hukum Perkawinan Tidak Dicatat Terhadap Istri Dan Anak Atas Hak Kebendaan Menurut Hukum Islam Di Indonesia, Jurnal AsySyari'ah, Vol 17, No.3 Desember 2015, hal 185

3 (Soemiyati, hukum Perkawinan Islam Di Indonesia Dan Undang-Undang Perkawinan Nomor 1 Tahun 1974, Liberty, Yogyakarta, 1986 hal.139.

4 Mohd. Idris Ramulyo, Hukum Perkawianan, Hukum Kewarisan, Hukum Acara Peradilan Agama Menurut Hukum Islam, Sinar Grafika, Jakarta, 2000 ; hal.45.

${ }^{5}$ Neng Jubaedah, Pencacatan Perkawinan dan Perkawinan Tidak Dicatat, Sinar Grafika, Jakarta, 2010, hal.376.

${ }^{6}$ Sudarsono, Hukum Perkawinan Nasional, Rineka Cipta, Jakarta,1991, hal.307.
} 
pasal 2 ayat (1) tersebut, maka dapat diartikan bahwa suatu perkawinan dapat dikatakan sah apabila perkawinan itu sudah dilakukan menurut hukum masing-masing agama dan kepercayaannya. Bagir Manan mengemukakan bahwa perkawinan yang sah adalah perkawinan yang memenuhi ketentuan Pasal 2 ayat (1) Undang-Undang Nomor 1 Tahun 1974, yaitu sah menurut agama yang mempunyai akibat hukum pula. Pencatatan perkawinan sebgaimana ditentukan dalam Pasal 2 ayat (2) Undang-undang Nomor 1 Tahun 1974 tidak menujukkan kualifikasi sederajad yang bermakna sahnya perkawinan menurut agama adalah sama dengan pencatatan perkawinan, sehingga yang satu dapat menganulir yang lain.

Ketentuan yang diatur dalam Pasal 2 ayat (2) tentang pencatatan perkawinan sampai saat ini masih menimbulkan banyak persoalan, yang kenyataannya pada masyarakat masih ada orang-orang yang telah melangsungkan perkawinan namun tidak mencatatkan perkawinannya, mereka hanya melakukan perkawinan yang menurut mereka sudah sah secara agama, tetapi perkawinan itu tidak tercatat menurut peraturan perundang-undangan. Perkawinan semacam ini disebut dengan perkawinan tidak tercatat. Hal ini dapat dipengaruhi beberapa faktor, diantarannya karena ketidaktahuan dan ketidaksadaran masyarakat akan hukum negara tentang perkawinan, mereka juga tidak mengetahui pentingnya dokumen perkawinan, atau juga perkawinan mereka tidak dicatat karena mereka tidak mampu membayar biaya pencatatan perkawinan, dan lain sebagainya.

Berdasarkan uraian tersebut di atas, maka dalam penelitian ini dirumuskan permasalahan sebagai berikut:

1. Bagaimana satatus hukum perkawinan yang tidak dicatat?

2. Bagaimana status hukum anak dari perkawinan yang tidak dicatat?

\section{METODE PENELITIAN}

Metode yang digukanan dalam penelitian ini yuridis normatif yaitu pendekatan terhadap permasalahan dengan memahami dan mengkaji peraturan perundang-undangan yang berkaitan dengan perkawinan. Dengan demikian maka sumber data yang digunakan adalah bahan hukum primer yaitu bahan-bahan hukum yang mengikat yang terdiri dari: Peraturan Perundangundangan tentang perasuransian, yurisprodensi, Traktat, dll; Bahan hukum sekunder yaitu bahan hukum yang memberikan penjelasan mengenai bahan hukum primer seperti; hasil penelitian, literatur, buku-buku dll.; Bahan hukum tersier yaitu bahan hukum yang menunjang bahan hukum primer dan bahan hukum sekunder misal kamus, ensiklopedia. Selanjutnya dari bahan hukum yang diperoleh tersebut dipilih dan dipilah-pilah sesuai dengan pokok permasalahan yang dibahas. Kemudian dilakukan analisa secara deskriptif kualitatif. ${ }^{8}$

\section{III.PEMBAHASAN}

\section{A. Status Hukum Perkawinan yang tidak dicatat}

Pasal 2 ayat (1) Peraturan Pemerintah Nomor 9 Tahun 1975 Tentang Pelaksanaan Undang-Undang Nomor 1 tahun 1974 Tentang Perkawinan, menyebutkan pencatatan perkawinan dari mereka yang melangsungkan perkawinan menurut agama islam dilakukan oleh pegawai pencatata Nikah, Talak dan Rujuk. Pasal 2 ayat (2) menyebutkan pencatatan perkawinan dari mereka yang melangsungkan perkawinannya menurut agamanya dan kepercayaannya itu selain agama islam, dilakukan oleh pegawai pencatatan perkawinan sipil.

Perkawinan tidak dicatat dalam tulisan ini adalah perkawinan yang memenuhi rukun dan syarat menurut agama dan kepercayaan masing-masing (sah menurut agama), namun tidak dicatatkan sebagaimana ketentuan yang diatur dalam UndangUndang Perkawinan. Sepasang kekasih yang telah melangsungkan perkawinan hendaknya mencatatkan perkawinannya tersebut pada instansi yang berwenang, karena fungsi dan kedudukan pencatatan perkawinan itu sangat penting yakni untuk menjamin adanya kepastian hukum bagi para pihak yang telah melangsungkan perkawinan.

Perkawinan merupakan suatu perbuatan hukum yang dapat menimbulkan akibat hukum berupa hak dan kewajiban bagi suami istri. Pada Pasal 30 Undang-Undang Nomor 1 Tahun 1974 menyebutkan bahwa: "suami istri memikul kewajiban yang luhur untuk menegakkan rumah tangga yang menjadi sendi dasar dari susunan masyarakat". Dalam hal ini bahwa menegakkan suatu rumah tangga yang bahagia, sejahtera, dan kekal untuk dijadikan sendi dasar susunan masyarakat, suami istri harus memiliki kewajiban yang sama dan luhur. Maka dari itu suami istri berkewajiban untuk hidup saling menghormati, saling mencintai, saling berkasih sayang, dan saling setia terhadap pasangannya.

Pada pasal 31 undang-Undang Nomor 1 Tahun 1974 menyebutkan: Ayat (1). Hak dan kedudukan istri adalah seimbang dengan hak dan kedudukan suami dalam kehidupan rumah tangga dan pergaulan hidup bersama dalam masyarakat. Ayat (2) Masingmasing pihak berhak untuk melakukan perbuatan hukum. Ayat (3) Suami adalah kepala keluarga dan istri adalah ibu rumah tangga.

Dalam hal ini maka antara suaimi dan isteri mempunyai hak dan kedudukan yang seimbang dalam kehidupan rumah tangga dan hubungan kemasyarakatan. Sehingga masing-masing pihak berhak untuk melakukan perbuatan hukum. Meskipun hak dan kedudukan antara suami istri adalah seimbang, tetapi mereka mempunyai peran dan tanggung jawab yang berbeda dalam keluarga, yaitu Suami sebagai Kepala rumah tangga dan Istri sebagai Ibu rumah tangga.

\footnotetext{
${ }^{7}$ Neng Djubaedah,Op. Cit, hal157-158.

${ }^{8}$ Soerjono Soekanto dan Sri Mamudji. Penelitian Hukum Normatof, Rajawali Press, Jakarta, 2003, hal. 13.
} 
Pada pasal 32 Undang-Undang Nomor 1 tahun 1974 disebutkan: ayat (1) Suami istri harus mempunyai tempat kediaman yang tetap; ayat(2) Rumah tempat kediaman yang dimaksud dalam ayat (1) pasal ini ditentukan oleh suami istri bersama. Tempat kediaman yang dimaksud adalah tempat tinggal yang layak huni bagi istri dan anak-anaknya, sehinnga mereka merasa terlindungi dari gangguan pihak lain, aman dan tentram serta terjaga privasi mereka. Penyediaan tempat kediaman menjadi kewajiban suami yang didasarkan pada kemampuan sang suami.

Pasal 33 Undang-Undang Nomor 1 Tahun 1974 yang menyebutkan bahwa: " Suami istri wajib saling cinta-mencintai, hormat menghormati, setia dan memberi bantuan lahir batin yang satu kepada yang lain”. Pasal 34 Undang-Undang Nomor 1 Tahun 1974, berbunyi: ayat (1) Suami wajib melindungi istrinya dan memberikan segala sesuatu keperluan hidup berumah tangga sesuai kemampuannya; ayat (2) Istri wajib mengatur urusan rumah tangga sebaik-baiknya; ayat (3) Jika suami atau istri melalaikan kewajibannya masing-masing dapat mengajukan gugatan ke Pengadilan.

Suami berkewajiban untuk memenuhi kebutuhan hidup dalam berumah tangga sesuai dengan penghasilannya, apabila istri juga bekerja maka ia tidak berkewajiban untuk menanggung biaya keperluan hidup rumah tangganya, kecuali sang istri ikhlas untuk menanggung kebutuhan hidup dalam rumah tanggannya. Seperti pada saat ini diera emansipasi wanita dan seiring dengan perkembangan zaman mengenai tanggung jawab dalam biaya keperluan hidup dalam rumah tangga tidak mutlak hanya dibebankan kepada si suami, tetapi si istri juga dapat membantu suaminya.

Keadaan pencatatan perkawinan lebih dikarenakan adanya dari ikatan lahir batin yang menyatukan tiga dimensi religius, sosial dan hukum, maka akan adanya konsekuensi yang berupa $:^{9}$

- Yuridis, sebagaimana diakui oleh masyarakat, perkawinan merupakan lembaga yang diakui oleh hukum, sehingga keutuhan dan keberlangsungan dalam sebuah tatanan kehidupan bermasyarakat dan bernegara dijamin oleh hukum.

- Biologis, meskipun sebelumnya diharamkan, setelah adanya ikatan lahir batin, antara suami istri yang melangsungkan akad nikah dihalalkan untuk hubungan intim biologis.

- Soaial, terbentuknya struktur sosial baik keluarga inti yang merupakan cikal bakal komunitas sosial.

- Politis, perkawinan dapat berimplikasi pada status kewarganegaraan, indikasi kedewasaan, status marital demografi.

- Ekonomis, perkawinan menimbulkan hak dan kewajiban, nafkah hidup, penyatuan pendapatan dan kewarisan.

Persoalan mengenai sahnya perkawinan tidak dicatat adalah murni ranah hukum agama dan kepercayaan yang dianut oleh calon mempelai, akan tetapi terkait dengan perkawinan itu diluar hukum agama yang mengaturnya, pemerintah juga merasa berkepentingan untuk melindungi warga negaranya. Salah satu cara yang dilakukan pemerintah adalah melakukan pencatatan peristiwa akad nikah yang dilangsungkan. Perkawinan dalam prosesnya melibatkan orang lain, maka harus dicatat, sehingga hal-hal yang terkait dengan peristiwa itu dan juga akibatnya menjadi jelas.

Jadi perkawinan yang tidak dicatat ini merupakan suatu perkawinan yang sah secara agama, namun tidak dicatat kepada instansi yang berwenang untuk mencatat perkawinan tersebut, maka dari itu perkawinan tidak dicatat di dalam hukum positif kita yaitu Undang-Undang Nomor 1 Tahun 1974 Perkawinan tersebut dianggap tidak sah atau tidak memiliki kekuatan hukum, karena perkawinan tersebut tidak diakui oleh Negara. Perkawinan dianggap tidak sah, meskipun perkawinan dilakukan menurut agama dan kepercayaan, namun dimata negara atau di mata hukum, subtansi perkawinan tersebut dianggap tidak sah jika belum dicatat di Kantor Urusan Agama atau Kantor Catatan Sipil. Maka perkawinan tersebut akan berdampak merugikan bagi si istri, dampak tersebut antara lain sebagai berikut: ${ }^{10}$

- Istri tidak dianggap sebagai istrinya yang sah. Akibatnya, suami dapat mengingkari atas perkawinannya.

- Istri tidak dapat menutut hak nafkah dan hak warisan jika suami meninggal dunia.

- Istri kurang mendapatkan perlindungan hukum bila terjadi kekerasan dalam rumah tangga karena secara hukum status suami terbebas dari tanggung jawab.

- Pihak istri tidak dapat memperoleh harta gono gini bila terjadi perpisahan atau perceraian.

- Istri mudah ditalak kapan saja, bakan suami dapt mengingkasi pernikahan yang telah terjadi.

Selain menimbulkan dampak secara hukum, perkawinan tidak tercatat juga menimbulkan dampak secara sosial, seperti pihak perempuan (si istri) biasanya dipandang sebelah mata oleh masyarakat sekitar, bahkan jadi bahan gunjingan para tetangga sehingga sulit bersosialisasi karena ada rasa malu. Seorang istri yang perkawinannya dilakukan secara tidak tercatat tersebut juga sangat mudah untuk dipermainkan oleh laki-laki yang tidak hidung belang.

\section{B. Status hukum anak dari perkawinan yang tidak dicatat.}

Terdapat berbagai macam anak yang dihasilkan dari suatu perkawinan, diantarannya adalah anak sah dan anak luar kawin. Dalam Kitab Undang-Undang Hukum Perdata dan Undang-Undang Perkawinan berlaku prinsip, bahwa keturunan yang sah didasarkan atas suatu perkawinan yang sah. ${ }^{11}$ Anak sah, merupakan anak yang dilahirkan dari suatu perkawinan yang sah, anak sah menempati kedudukan yang paling tinggi dan paling sempurna dimata hukum, karena anak sah menyangdang seluruh hak yang diberikan oleh hukum, antara lain hak waris, hak sosial dimana ia mendapatkan status yang terhormat di lingkungan masyarakat.

\footnotetext{
${ }^{9}$ H. Endang Ali Ma’sum, Perkawinan Yang Tidak Dicatat Dan Problematikanya, Jurnal Musawa, Vol. 12, No.2 Juli 2012, hal.202-203.:

${ }^{10}$ H. Endang Ali Ma'sum, Op. Cit. hal.209

${ }^{11}$ J.Satrio, Hukum Keluarga Tentang Kedudukan Anak Dalam Keluarga, Citra Aditya Bakti, Bandung, 2000, hal 18.
} 
Pasal 42 Undang-Undang Perkawinan menyebutkan bahwa: "Anak sah adalah anak yang dilahirkan dalam atau sebagai akibat dari perkawinan sah". Pasal 43 ayat (1) anak yang dilahirkan di luar perkawinan hanya mempunyai hubungan perdata denagn Ibunya. Dalam hal ini berarti anak yang dihasilkan dari perkawinan yang tidak tercatat berstatus sebagai anak luar kawin, yang berarti berstatus sebagai anak tidak sah dan tidak memiliki hubungan perdata dengan ayahnya. Anak tersebut hanya memiliki hubungan perdata dengan ibunya., yang berarti tidak berhak atas biaya hidup dan pendidikan,termasuk juga nafkah dan warisan dari ayahnya. Si istri dan anak hanya dapat mengharap belas kasih dari ayahnya, jika si ayah ini tidak memiliki rasa belas kasih terhadap istri dan anaknya maka istri dan anak tersebut tidak akan mendapat apa-apa, jika akan menuntut nafkah juga sulit karena tidak memiliki bukti adanya perkawinan.

Anak-anak yang berstatus anak luar kawin juga sangat rentan terhadap kekerasan, mereka kurang memperoleh kasih sayang terutama dari sang ayah karena hubungan antara ayah dengan anak tidak kuat, maka akan berakibat terhadap anak tersebut, kareana dapat mempengaruhi tumbuh kembang si anak, bisa juga anak tersebut menjadi terlantar. Hal ini tentu sangat bertentangan dengan ketentuan pada pasal 45 Undang-Undang Nomor 1 tahun 1974 yang berbunyi: ayat (1) kedua orang tua wajib memelihara dan mendidik anak-anak mereka sebaik-baiknya; ayat (2) kewajiban orang tua yang dimaksud dalam ayat (1) pasal ini berlaku sampai anak itu kawin atau dapat berdiri sendiri, kewajiban mana berlaku terus meskipun perkaiwnan antara kedua orang tua putus.

Perkawinan tidak dicatat tidak memberikan perlindungan terhadap kaum perempuan sebagai istri dan juga anak-anak hasil dari perkawinan yang tidak dicatat. Perkawinan yang tidak dicatat ini merugikan kaum istri dan anak-anak hasil dari perkawinan yang tidak dircatat, perkawinan yang tidak dicatat ini juga tidak memberikan jaminan terhadap hak-hak istri untuk dipenuhi oleh suami sebagaimana diatur dalam pasal 30, 31, 33, dan 34 Undang-Undang Nomor 1 tahun 1974.

Perkawinan yang tidak dicatat ini juga tidak memberikan jaminan terhadap hak-hak anak dari hasil perkaiwinan yang tidak dicatat sebagaimana yang diatur dalam pasal 45 undang-undang nomor 1 tahun 1974 tentang perkawinan. jadi dalam hal ini status anak yang dihasilkan dari perkawinan yang tidak dicatat anak tersebut hanya mempunyai hubungan perdata dengan ibunya dan keluarga ibunya saja, ini terdapat dalam pasal 43 undang-undang nomor 1 tahun 1974 tentang perkawinan.

Anak yang lahir dari perkawinan yang tidak dicatat ini tidak mempunyai hubungan perdata dengan ayahnya dan keluarga ayahnya, anak ini juga tidak dapat menuntut hak-haknya sebagai seorang anak dan juga anak tersebut tidak berhak atas harta kekayaan dari ayahnya, karena anak itu juga tidak memiliki alat bukti yang sah karena perkawinan yang dilakukan oleh kedua orang tuanya adalah perkawinan yang tidak dicatat dan tidak memiliki bukti bahwa kedua orang tuanya telah melangsungkan perkawinan yang sah.

Kedudukan seorang anak di dalam hal kewarisan itu penting, karena anak merupakan keturunan atau penerus dari orang tuanya. Anak yang dilahirkan diluar perkawinan hanya mempunyai hubungan perdata dengan ibunya saja, oleh karena itu anak luar kawin hanya memperoleh warisan dari ibunya maupun keluarga ibunya saja, anak tersebut tidak berhak warisan dari ayahnya karena ia tidak mempunyai hubungan perdata dengan ayahnya.

Terkait dengan hak anak dari hasil perkawinan yang dilakukan sesuai dengan prosedur agama dan kepercayaannya tapi tidak dicatatkan di Kantor Urusan Agama atau Kantor Catatan Sipil. Setelah adanya putusan Mahkamah Konstitusi pada tahun 2010 maka si anak tersebut akan mendapat hak dari ayah bilogisnya asalkan dapat membuktikannya, bawa dia benar-benar anak adri ayah yang dimaksud.

Putusan mahkamah Konstitusi Nomor 46/PUU-VIII/2010 mencerminkan prinsip persamaan di hadapan hukum sebagaimana yang dimaksud dalam Pasal 28 D ayat (1) Undang-Undang Dasar 1945 yang berbunyi: Setiap orang berhak atas pengakuan, jaminan, perlindungan dan kepastian hukum yang adil serta perlakuan yang sama dihadapan hukum". Dampak positif dari Putusan Mahkamah Konstitusi Nomor 46/PUU-VIII/2010 menyatakan bahwa Pasal 43 ayat (1) Undang-Undang Nomor 1 Tahun 1974 tentang Perkawinan yang berbunyi "Anak yang dilahirkan di luar perkawinan hanya mempunyai hubungan perdata dengan ibunya dan keluarga ibunya" bertentangan dengan UUD 1945 dan tidak memiliki kekuatan hukum mengikat sepanjang dimaknai menghilangkan hubungan perdata dengan laki-laki yang dapat dibuktikan berdasarkan ilmu dan teknologi dan/atau alat bukti lain menurut hukum ternyata mempunyai hubungan darah sebagai ayahnya, sehingga ayat tersebut harus dibaca,"Anak yang dilahirkan di luar perkawinan mempunyai hubungan perdata dengan ibunya dan keluarga ibunya serta dengan laki-laki sebagai ayahnya yang dapat dibuktikan berdasarkan ilmu pengetahuan dan teknologi dan/atau alat bukti lain menurut hukum mempunyai hubungan darah, termasuk hubungan perdata dengan keluarga ayahnya".

Putusan ini menimbulkan konsekuensi adanya hubungan darah anak luar kawin dengan bapak biologisnya, adanya hak dan kewajiban antara anak luar kawin dan bapak biologisnya, baik dalam bentuk nafkah, waris dan lain sebagainya. Hal ini dapat berlaku apabila dilakukan dilakukan pembuktian melalui ilmu pengetahuan dan teknologi seperti : tes DNA dan lain sebagainya yang dapat menyatakan bahwa benar anak diluar kawin tersebut memiliki hubungan darah dengan laki-laki sebagai ayah biologisnya. Maka jika anak tersebut dapat terbukti memiliki hubungan darah dengan ayah biologisnya, anak tersebut dapat memiliki kesempatan untuk mendapatkan hak nafkah, warisan, dan sebagainya.

Putusan Mahkamah Konstitusi tersebut bertolak dari ketentuan pasal 2 ayat (2) undang-undang nomor 1 tahun 1974 tentang perkawinan yang menyatakan: "Tiap- tiap perkawinan dicatat menurut peraturan perundang-undangan yang berlaku" ketentuan tersebut tentulah sebuah perkawinan dalam pandangan Negara adalah apabila perkawinan yang dilakukan dicatatkan atau tercatat pada lembaga yang ditugasi untuk itu. Artinya perkawinan sebuah lembaga bisa terjadi menurut cara yang sudah diatur dalam undang-undang, dan bisa pula terjadi diluar prosedur yang telah ditetapkan undang-undang misalnya perkawinan yang sah menurut agama namun tidak dicatat secara resmi pada lembaga yang mengurus perkawinan. 
Ketentuan Pasal 2 ayat (2) UU No. 1 Tahun 1974 tentang Perkawinan itu tentulah tidak sama maksudnya dengan anakanak yang lahir dari sebuah hubungan perzinahan. Dalam kaitan ini "anak yang lahir diluar perkawinan" sebagaimana dituangkan dalam pasal 2 ayat 2 UU No 1 Tahun 1974 tentu terkait dengan proses sebuah perkawinan yang menurut agama tetapi tidak dicatat pada lembaga perkawinanan sebagaimana ditentukan peraturan perundang-undangan.

Dalam Putusan Mahkamah Konstitusi Nomor 46/PUU-VIII/2010 tidaklah dalam konteks pembuktian yang ditujukan kepada anak yang lahir dari hahubungan perzinahan, melain ditujukan kepada anak yang lahir diluar perkawinan yang hanya karena tidak dilakukan menurut prosedur menurut ketentuan Undang-Undang Nomor 1 Tahun 1974 Tentang Perkawinan.

\section{KESIMPULAN}

Dari uraian pembahasan tersebut dapat disimpulkan sebagai berikut :

1. Status hukum perkawinan yang tidak dicatat dalam menurut hokum perkawinan adalah tidak sah atau tidak memiliki kekuatan hukum. Suatu keabsahan perkawinan menurut Undang-Undang Nomor 1 Tahun 1974, Perkawinan itu dikatakan sah apabila perkawinan tersebut telah sesuai dengan ketentuan yang terdapat dalam pasal 2 ayat (1) dan ayat (2).

2. Status hokum anak yang dilahirkan dari perkawinan yang tidak dicatat mempunyai hubungan perdata dengan ibunya (terdapat dalam pasal 43 Undang-Nndang nomor 1 Tahun 1974 Tentang Perkawinan), hal ini membawa konsekuensi bahwa anak yang dilahirkan dari perkawinan tidak dicatat secara hukum Negara anak tersebut tidak memiliki hubungan perdata dengan ayahnya. Namun setelah adanya Putusan Mahkamah Konstitusi Nomor 46/PUU-VIII/2010 yang mana si anak tersebut juga bisa memiliki hubungan perdata dengan ayahnya asalkan dapat dibuktikan dengan alat-alat tekhnologi seperti Tes DNA.

\section{REFERENSI}

\section{A. Buku:}

H.S.A. Al Hamdani, 2002, Risalah Nikah, Jakarta, Pustaka Amani.

J.Satrio, 2000, Hukum Keluarga Tentang Kedudukan anak Dalam Keluarga, Bandung, Citra Aditya Bakti

Mohd. Idris, 2000, Hukum Perkawinan,Hukum Kewarisan, Hukum Acara Peradilan Agama Menurut Hukum Islam, Jakarta, Sinar Grafika.

Neng Djubaedah, 2010, Pencatatan Perkawinan Dan Perkawinan Tidak Dicatat Menurut Hukum Tertulis Di Indonesia Dan Hukum Islam, Jakarta, Sinar Grafika.

Soemiyati, 1986, Hukum Perkawinan Islam dan Undang-Undang Perkawinan No.1 Tahun 1974, Yogyakarta, Liberty.

Sudarsono, 1991, Hukum Perkawinan Nasional, Jakarta, Rineka Cipta.

Soerjono Soekanto dan Sri Mamudji. 2003, Penelitian Hukum Normatof, Jakarta, Rajawali Press.

\section{B. Jurnal:}

Endang Ali Ma’sum, 2013, Perkawinan Yang Tidak Dicatatkan Dan Problematikanya, Jurnal Musawa, Vol.12 No.2 Juli 2012.

Siah Khosyi'ah, 2015, Akibat Hukum Perkawinan Tidak dicatat Terhadap Istri dan Anak atas Hak kebendaan Menurut Hukum Islam Di Indonesia, Jurnal Asysyari'ah, Vol. 17 No. 3 Desember 2015.

\section{Peraturan Perundang-undangan :}

Undang-Undang Dasar Republik Indonesia 1945

Undang-Undang Republik Indinesia Nomor 1 Tahun 1974 tentang Perkawinan

Undang-Undang Republik Indonesia Nomor 23 Tahun 2006 Tentang Adnimistrasi Kependudukan.

Peraturan Pemerintah Nomor 9 Tahun 1975 Tentang Pelaksanaan Undang-Undang Nomor 1 Tahun 1974 tentang Perkawinan.

\section{Keputusan:}

Putusan Mahkamah Konstitusi Nomor 46/Puu-VIII/2010, dalam Perkara Permohonan Pengujian Undang-Undang Nomor 1 Tahun 1974 Tentang Perkawinan, yang diajukan oleh aisyah Muchtar alias Machica Muchtar dan Muhammad Iqbal. 